$\square$ 원 저 $\square$

$$
\begin{gathered}
\text { 수면무호흡증의 중증도와 안정시 에너지 대사 } \\
\text { 및 혈중 Leptin과의 관계 }
\end{gathered}
$$

영남대학교 의과대학 내과학교실

이관호, 신경철, 안재회

\title{
$=$ Abstract $=$ \\ The Relationship of the Severity of Sleep Apnea Syndrome to the Resting Energy Expenditure and Leptin
}

\author{
Kwan Ho Lee, M.D., Kyeong Cheol Shin, M.D., Jee Hee Ahn M.D. \\ Department of Internal Medicine, College of Medicine, Yeungnam University, Taegu, Korea
}

Background : Obesity is present in the majority of adult patients with obstructive sleep apnea(OSA) and is considered to be a major risk factor for its development. A reduction in body weight has been associated with substantial improvement in the severity of apnea. However, a variety of treatment strategies for obesity have yielded limited sucess. This study was done to determine resting energy expenditure( $R E E$ ) in patients with obstructive sleep apnea and the correlation between the severity of sleep apnea and REE, and to investigate whether leptin influences REE and correlated with the severity of sleep apnea in 39 patients with OSA and 45 controls matched for obesity.

Method : Overnight polysomnography was performed on all subjects using standard techniques. Measurements of REE were made using a Sensormedic Vmax 229 and a canopy system. Serum leptin concentration was measured by human leptin RIA kit of LINCO Research INC.

Results : REE was greater in patients with OSA compared with controls, but there was no difference between the two groups on REE\%. And also there was no significant correlation between anthropometric data, polysomnographic data and REE\%. Serum leptin was linearly related to body mass index(BMI), apnea index, apnea $\cdot$ hypopnea index and lowest arterial oxygen saturation $\left(\mathrm{SaO}_{2}\right)$ but not related to $\mathrm{REE} \%$.

Conclusion : This study suggests the followings. Firstly patients patients with sleep apnea have a pattern of obesity characterized by energy homeostasis at an elevated body weight set-point. In order to achieve a lower body weight in these patients, it may be necessary to increase energy expenditure by increasing physical activity. Secondly leptin level was not correlated with REE, suggesting that leptin may predominantly regulate body fat by altering eating behavior rather than calorigenesis. Lastly leptin level was significantly correlated with the severity of sleep apnea. These elevated level of leptin in patients of sleep apnea may be related to the 
- The relationship of the severity of sleep apnea syndrome to the resting -

obesity, however it needs further studies to determine the relationship between the severity of sleep apnea and serum leptin. (Tuberculosis and Respiratory Diseases 1999, 46 : 836-845)

Key words : Obstructive sleep apnea, Resting energy expenditure, Leptin.

\section{서 톤}

수면무호홉중은 수면 중 반복적인 호흡 정지로 인한 동맥혈 저산소혈중으로 심폐기능 부전, 말초혈관기눙 장애나 중추신경 질환을 일으킬 뿐만 아니라 갑작스런 사망의 원인이 되기도 하며, 소아에서는 성장 장애가 일어나기도 한다1, 2). 대부분의 수면무호흡중 환자에서 비만이 동반되며 비만은 수면무호흡중 발병의 중요한 원인으로 알려져 있닿. 비만한 사랍의 수면무호흡중 발병률에 대해서는 정확하게 알려져 있지 않으나 비만 정도와 수면무호합과는 관계가 많으며 수면무호흡중 의 치툐로 가장 먼저 시도되는 것이 체중 감소이다45). 체중감소가 무호흡을 줄이고, 동맥혈 산소 포화도를 향상시키며 심부정맥을 감소시킬 수 있다는 사실이 알 려지면서 비만을 조절하기 위하여 식이요법, 행동요 법, 심리치료 등과 같은 여러 가지 방법이 시도되었으 나 현재까지 만족스럽지 못한 실정이다 ${ }^{1.6)}$.

하루에 소모되는 전체에너지의 약 $70 \%$ 가 안정시 소모되는 에너지이며, 에너지대사는 잠들기 시작할 때 감소하기 시작하여 이른 아침에 가장 낮은 일일 변화 주기성을 보인다 ${ }^{78)}$. 수면무호흡중 환자는 주간의 과 도한 졸음과 이로 인한 활동양의 감소로 에너지소모가 줄어들어 전체 에너지 소보량은 감소할 것으로 추측할 수 있다. 최근 대부분 비만한 사람은 혈중 leptin 농 도가 상숭되어 있는 것이 발표되었으며, 비만한 사람 일수록 혈중 leptin 농도가 높게 나타나지만, leptin 생성이 증가되었다기보다는 leptin 작용에 대한 저항 성 때문인 것으로 알려지고 있다일. 수면무호흡중 환 자의 혈중 leptin 농도에 관해서는 아직까지도 잘 알 려져 있지 않으며, 수면무호훕증의 중중도와 혈중 leptin 농도와의 관계에 대해서도 알려져 있지 않다.

저자듈은 이 연구에서 수면무호합중이 안정시 에너
지대사에 미치는 영향을 관찰하고, 수면다원검사에서 측정한 수면무호흡증의 중중도와 안정시 에너지소모 량과의 상관관계를 규명하려 하였으며, 또한 수면무호 흡중에서 혈중 leptin 농도를 측정하여 수면무호흡중 의 중증도와 leptin 농도와의 관계를 알아보고자 하였 다.

\section{대상 및 방법}

대상환자 및 대조군의 선택 : 수면무호흡중이 의심되 어 영남대학교 의과대학 부속병원에서 수면다원검사 (polysomnography)를 받은 84명의 환자를 대상으 로 하였다. 이 중 수면무호흡중군 39 례와 무호흡이 없었던 45 례를 대조군으로 하였다. 수면무호흡증은 수면다원검사상 무호흡지수(apnea index : Al) 가 5 이상이거나 호홉부전지수(respiratory disturbance index : RDI) 가 10 이상이면서 신체질량지수(body mass index, $\mathrm{BMI}$ )가 $25 \mathrm{~kg} / \mathrm{m}^{2}$ 이상으로 정의 하였 으며, 수면다원검사상 수면 중 무호홥이 없고 신체질 량지수만 $25 \mathrm{~kg} / \mathrm{m}^{2}$ 이상인 사람을 대조군으로 하였 다. 검사자 중 에너지대사 이상을 초래할 수 있는 갑 상선 질환, 당뇨병, 감염증, 악성종양 환자와 최근 5 $\%$ 이상의 체중 변화가 있었던 사람, 그리고 심혈관계 및 호흡기 계통의 질병을 갖고 있는 사람은 대상에서 제외하였다. 모든 수면무호합증군과 대조군을 대상으 로 나이, 신장, 체중, 신체질량지수를 측정하였으며 목 둘레는 윤상갑상막의 위치에서 측정하여 비교하였다. 수면다원검사 (polysomnograph) : 수면다원검사는 조용하고 어두운 방에서 실시하였으며 수면을 유도하 기 위하여 진정제를 사용하지는 않았다. 검사 당일 카 페인이 포함된 음료는 마시지 못하게 하였으며 검사 전 3 시간 이내에는 음료수 및 옴식물 섭취를 금하 
였다.

수면다원검사는 독일 MAP사의 ED24를 사용하였 고 수면 및 수면 단계는 표준체표전극으로 두 채널의 뇌전도, 두 채널의 안전도, 두 채널의 근전도 및 심전 도 등으로 기록하여 수면여부를 판정하였다. 호홉 유 무는 비강과 구강 thermister로, 흥부 및 복부의 호 홉운동은 pneumobelt로, 동맥혈 산소포화도는 oximeter(Sat-Trak pulse oximeter, Sensormedics Corporation, YobaLinda, California)로 각각 기록 하였다.

판독은 무호홉은 10 초 이상 구강이나 비강으로 공 기 흐름이 없는 경우로 하였으며, 저호흡은 10 초 이 상 선행하는 정상 기도 흐름이 $50 \%$ 이상 감소한 경 우로 정의하였다. 무호흡지수(apnea/hour of sleep) 는 수면시간당 무호홉 햇수로, 호합부전지수(apnea +hypopnea/hour of sleep)는 수면시간당 무호홉과 저호흡 횟수의 합으로 판정하였다.

간접 칼로리측정 (indirect calorimetry) : 안정시 에 너지소모량(resting energy expenditure, $\mathrm{REE}$ ) 측 정은 오후 9시 이후부터 금식을 하고 수면다원검사를 실시 한 후, 다음날 아침 6시경 침상에 편안히 누워 깨어있는 상태에서 측정하였다. 환자는 침상에서 약 30 분 동안 안정을 취한 후 canopy(Beckman Canopy Systems, Anheim, California)를 환자의 머리에 씨우고 목은 단단하게 조여서 호홉이 canopy 바같으 로 새어나가지 않게 하였으며 호기 이산화탄소 $\left(\mathrm{FECO}_{2}\right)$ 는 $0.65 \%$ 와 $0.85 \%$ 사이를 유지하게 하였 다. 안정시 에너지소모량은 ventilated hood system 을 이용한 Sensormedics Vmax 229의 indirect calorimeter(Sensormedics Corporation, Yoba Linda, California)를 이용하여 4 초마다 호기와 흡기의 산소 농도, 이산화탄소농도와 호기량을 측정하여 안정상태 에 도달할 때까지 산소 소모량 $\left(\mathrm{VO}_{2}\right)$ 과 이산화탄소 생성량 $\left(\mathrm{VCO}_{2}\right)$ 을 측정하였다. 안정상태는 분당 환기 량 $\left(\mathrm{V}_{\mathrm{E}}\right)$ 과 산소 소모량이 $10 \%$ 이하이면서 호흡 상 수(respiratory quotient)가 $5 \%$ 이하로 되었을 때 로 하였다. 모든 검사자는 5 분 내지 10 분 이내에 안
정상태에 도달하였다. 안정시 에너지소모량은 Weir 공식, 즉 measured $\mathrm{REE}(\mathrm{kcal} / \mathrm{day})=\left[3.9 \mathrm{VO}_{2}(\mathrm{~L}\right.$ $\left./ \mathrm{min})+1.1 \mathrm{VCO}_{2}(\mathrm{~L} / \mathrm{min})\right] \times 1440$ 을 사용하였다. 각 검사자의 안정시 에너지소모량의 예측치는 체중, 신장, 연령과 성별을 기준으로 다음과 같은 HarrisBenedict 공식을 이용하여 구하였다.

Harris-Benedict formula :

Female basal metabolic rate(kcal/day)

$$
\begin{aligned}
= & 655+[9.5 \times \text { B.W. }(\mathrm{kg})]+[1.8 \times \mathrm{Ht} .(\mathrm{cm})] \\
& -[4.7 \times \operatorname{Age}(\mathrm{yrs})]
\end{aligned}
$$

Male basal metabolic rate(kcal/day)

$$
\begin{aligned}
= & 66+[14.7 \times \text { B.W. }(\mathrm{kg})]+[5 \times \mathrm{Ht} .(\mathrm{cm})] \\
& -[6.8 \times \mathrm{Age}(\mathrm{yrs})]
\end{aligned}
$$

$\mathrm{REE}$ 의 백분율(REE\%)은 $\mathrm{REE}$ 예측치에 대한 $\mathrm{REE}$ 측정치의 비율로 구하였다.

함중 leptin농도의 측정 : 대상 환자에서 수면다원검 사를 시행한 다옴날 아침, 공복에 채혈하여 혈청을 분 리한 후 $-20^{\circ} \mathrm{C}$ 에 냉동 보관하였다. 혈청은 분석 직전 녹여 사용하였고 혈중 leptin 농도는 Linco Research사의 human leptin RIA kit를 사용하여 측정하 였다. 시험관에 $100 \mu \mathrm{L}$ 의 완충액을 넣고 환자의 혈청 $100 \mu \mathrm{L}$ 를 완충액이 든 시험관에 넣었다. Radioactive labelling을 위하여 ${ }^{125}$ I-human leptin $100 \mu \mathrm{L}$ 를 시헙관에 넣고 human-leptin antibody(Rabbit anti-human serum) $100 \mu \mathrm{L}$ 를 넣어 잘 섞은 후 4 ${ }^{\circ} \mathrm{C}$ 에서 20-24시간 동안 반웅시켰다. 다음날 Goat anti-Rabbit IgG serum을 이용한 precipitating reagent $1.0 \mathrm{~mL}$ 를 넣어 잘 석은 다옴 $4{ }^{\circ} \mathrm{C}$ 에서 20 분간 반웅시킨 후 원심분리하여 상청액은 버리고 15-60초 간 시험관을 건조시겼다. 건조된 시험관은 Packard 사의 Cobra 2 gamma counter를 이용하여 혈중 leptin 농도를 측정하였다. 이 측정법은 $0.5 \mathrm{ng} / \mathrm{mL}$ 까 지 눈석이 가능하며, 분석의 intra-assay coefficient 와 inter-assay coefficient는 각각 $5.0 \%$ 및 $4.5 \%$ 이었다.

통계처리 : 통계처리는 SPSS/PC+ 를 이용하여 two -tailed unpaired t-test를 사용하였으며, 수면무호흡 
- The relationship of the severity of sleep apnea syndrome to the resting -

중의 중중도와 안정시 에너지소모량과 leptin 둥과의 상관관계는 다중선형회귀분석(multiple linear regression)으로 분석하였다.

\section{결 과}

대상 환자중 수면무호합중군은 39례 이었으며 수면다 원검사가 정상이었던 대조군은 45 례 이었다. 대상 환 자의 평균 나이는 수면무호흡중군이 $44.1 \pm 10.2$ 세, 대조군이 $46.3 \pm 12.2$ 세, 신장은 수면무호합증군이 $168.9 \pm 7.7 \mathrm{~cm}$, 대조군이 $166.9 \pm 1.6 \mathrm{~cm}$, 체중은 수면무호흡중군이 $82.1 \pm 9.9 \mathrm{~kg}$, 대조군이 $78.0 \pm$ $13.3 \mathrm{~kg}$ 로 두 군 사이에 차이는 없었다. 목둘레는 수
면무호흡중군이 $15.9 \pm 1.0 \mathrm{~cm}$, 대조군이 $15.5 \pm 1.2$ $\mathrm{cm}$, 신체질량지수는 수면무호합중군이 $26.8 \pm 3.3 \mathrm{~kg}$ $/ \mathrm{m}^{2}$, 대조군이 $25.7 \pm 2.8 \mathrm{~kg} / \mathrm{m}^{2}$ 로 두 군 사이에 차 이는 없었다(Table 1).

수면다원검사 결과, 전체수면시간은 수면무호흡중 군이 $341.8 \pm 47.6$ 분, 대조군 $300.7 \pm 74.1$ 분으로 수 면무흡증군이 더 길었으며 $(\mathrm{p}<0.05)$, 수면효율성은 수면무호흡중군이 $84.1 \pm 10.9 \%$, 대조군이 $77.0 \pm$ $17.2 \%$ 로 수면무호흡증군에서 높았으나 $(\mathrm{p}<0.05)$, $\mathrm{REM}$ 수면시간은 두 군사이에 차이가 없었다. 무호흡 지수는 수면무호홉중군이 $21.2 \pm 13.9$ 로 대조군의 0. $9 \pm 1.1$ 보다 높았고 $(\mathrm{p}<0.05)$, 무호합 - 저호합 지수는 수면무호흡중군이 $32.5 \pm 18.8$ 로 대조군의 2.6

Table 1. Anthropometric data in patients with obstructive sleep apnea and control

\begin{tabular}{lcc}
\hline \hline Variables & OSA(N=39) & Control $(\mathrm{N}=45)$ \\
\hline Age, years & $44.1 \pm 10.2$ & $46.3 \pm 12.2$ \\
Height, cm & $168.9 \pm 7.7$ & $166.9 \pm 1.6$ \\
Weight, kg & $82.1 \pm 9.9$ & $78.0 \pm 13.3$ \\
Neck size, cm & $15.9 \pm 1.0$ & $15.5 \pm 1.2$ \\
BMI, kg $/ \mathrm{m}^{2}$ & $26.8 \pm 3.3$ & $25.7 \pm 2.8$ \\
\hline
\end{tabular}

Values are means $\pm \mathrm{SD}$.

OSA = obstructive sleep apnea ; $\mathrm{BMI}=$ body mass index.

Table 2. Polysomnographic data in patients with obstructive sleep apnea and control

\begin{tabular}{lcc}
\hline \hline Variables & OSA(N=39) & Control(N=45) \\
\hline TST, min & $341.8 \pm 47.6^{*}$ & $300.7 \pm 74.1$ \\
$\mathrm{SE}, \%$ & $84.1 \pm 10.9^{*}$ & $77.0 \pm 17.2$ \\
$\mathrm{REM}, \%$ & $6.1 \pm 4.3$ & $5.0 \pm 3.1$ \\
$\mathrm{Al}, /$ hour & $21.2 \pm 13.9^{*}$ & $0.9 \pm 1.1$ \\
$\mathrm{AHI}, /$ hour & $32.5 \pm 18.8$ & $2.6 \pm 3.6$ \\
Lowest $\mathrm{SaO}_{2}, \%$ & $77.1 \pm 7.5^{*}$ & $85.4 \pm 7.3$ \\
Mean $\mathrm{SaO}_{2}, \%$ & $92.5 \pm 2.2^{*}$ & $93.7 \pm 2.4$ \\
\hline
\end{tabular}

Values are means $\pm S D .{ }^{*} p<0.05$ vs control.

$\mathrm{OSA}=$ obstructive sleep apnea ; TST =total sleep time; $\mathrm{SE}=$ sleep efficiency ; $\mathrm{REM}=$ rapid eye movement $; \mathrm{AI}=$ apnea index $; \mathrm{AHI}=$ apnea $\cdot$ hypopnea index $; \mathrm{SaO}_{2}=$ arterial oxygen saturation. 
Table 3. Results of indirect calorimetric data and serum leptin in patients with obstructive sleep apnea and control

\begin{tabular}{lcc}
\hline \hline Variables & OSA $(\mathrm{N}=39)$ & Control $(\mathrm{N}=45)$ \\
\hline REE, predicted, kcal/day & $1665.8 \pm 241.0^{*}$ & $1504.9 \pm 219.9$ \\
REE, measured, kcal/day & $1539.8 \pm 338.7^{*}$ & $1377.1 \pm 212.0$ \\
REE, \% & $92.2 \pm 14.0$ & $92.3 \pm 13.0$ \\
Serum leptin, $\mu \mathrm{g} / \mathrm{L}$ & $8.9 \pm 5.5$ & $7.8 \pm 7.1$ \\
\hline
\end{tabular}

Values are means $\pm \mathrm{SD} .{ }^{*} \mathrm{p}<0.05$ vs control.

$\mathrm{OSA}=$ obstructive sleep apnea ; $\mathrm{REE}=$ resting energy expenditure.

\pm 3.6 보다 수면무호홉증군에서 높았다 $(\mathrm{p}<0.05)$. 동

맥혈 최저산소포화도는 수면무호흡증군이 $77.1 \pm 7.5$ $\%$, 대조군은 $85.4 \pm 7.3 \%$ 로 수면무흡중군에서 뚜렷 이 저하되어 있었다 $(\mathrm{p}<0.05)$ (Table 2).

수면무호홉증 및 대조군의 안정시 에너지소모량의 측정치는 각각 $1539.8 \pm 338.7 \mathrm{kcal} / \mathrm{day}, 1377.1 \pm$ $212.0 \mathrm{kcal} / \mathrm{day}$ 로 수먼무호흡증군에서 더 높았다 ( $\mathrm{p}$ $<0.05)$. 안정시 에너지소모량의 예측치는 수면무호 홉증군과 대조군에서 각각 $1665.8 \pm 241.0 \mathrm{kcal} / \mathrm{day}$, $1504.9 \pm 219.9 \mathrm{kcal} / \mathrm{day}$ 로 예측치도 수면무호흡중 군에서 더 높았다 $(\mathrm{p}<0.05)$. 그러나 안정시 에너지소 모량의 예측치에 대한 측정치의 백분율( $\mathrm{REE} \%$ )은 수면무호흡증군과 대조군이 각각 $92.2 \pm 14.0 \%, 92.3$ $\pm 13.0 \%$ 로 두 군 사이의 차이는 없었다. 수면무호흡

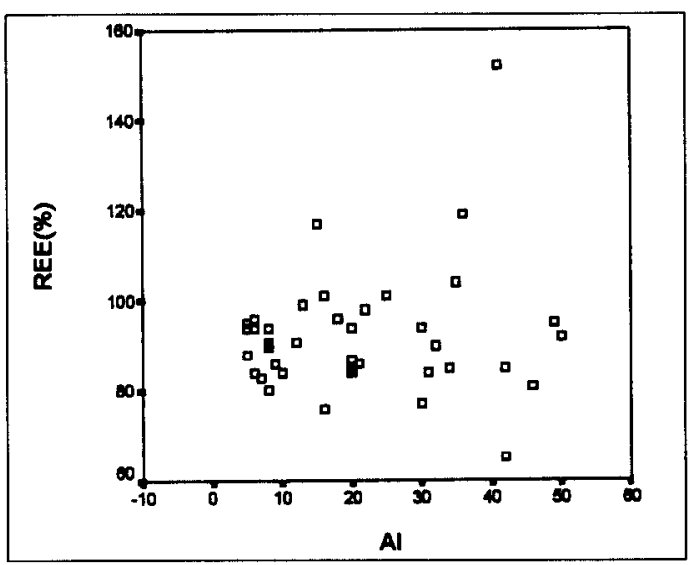

Fig. 1. Correlation between resting energy expenditure(REE) and apnea index(AI) in patients with obstructive sleep apnea.
중군과 대조군에서 측정한 혈중 leptin 농도는 각각 $8.9 \pm 5.5 \mu \mathrm{g} / \mathrm{L}, \quad 7.8 \pm 7.1 \mu \mathrm{g} / \mathrm{L}$ 로 차이가 없었다 (Table 3).

수면무호흡증에서 안정시 에너지소모량의 백분율과 인체계측인자 및 수면다원검사 소견상의 무호흡의 심 한 정도와의 선형 상관관계를 알아본 결과 인체계측인 자로 신장, 체중, 묵둘레 및 신체질량지수 등과는 유 의한 선형 상관관계가 없었다. 수면다원검사 소견중 전체수면시간, 수면 효율성, REM 수면시간 둥과 안 정시 에너지소모량의 백분율과도 상관관계는 없었다. 수면 무호흡증의 중중도와 관계있는 무호흡지수(Fig. 1), 무호흡-저호홉지수(Fig. 2) 및 동맥혈 최저산 소포화도(Fig. 3)와 안정시 에너지소모량의 백분율

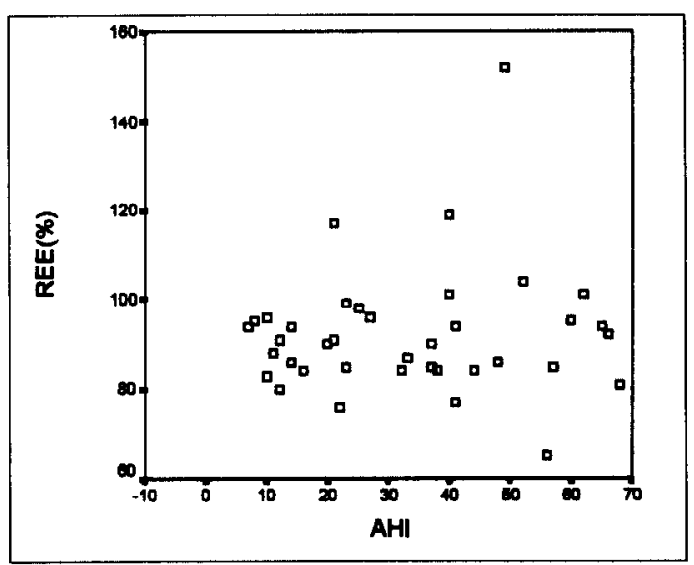

Fig. 2. Correlation between resting energy expenditure(REE) and apnea-hypopnea index(AHI) in patients with obstructive sleep apnea. 
- The relationship of the severity of sleep apnea syndrome to the resting -

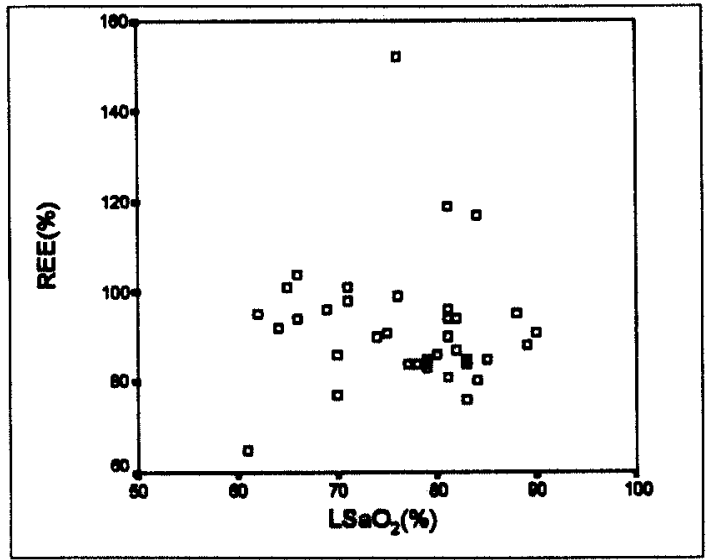

Fig. 3. Correlation between resting energy expenditure(REE) and lowest arterial oxygen saturation $\left(\mathrm{LSaO}_{2}\right)$ in patients with obstructive sleep apnea.

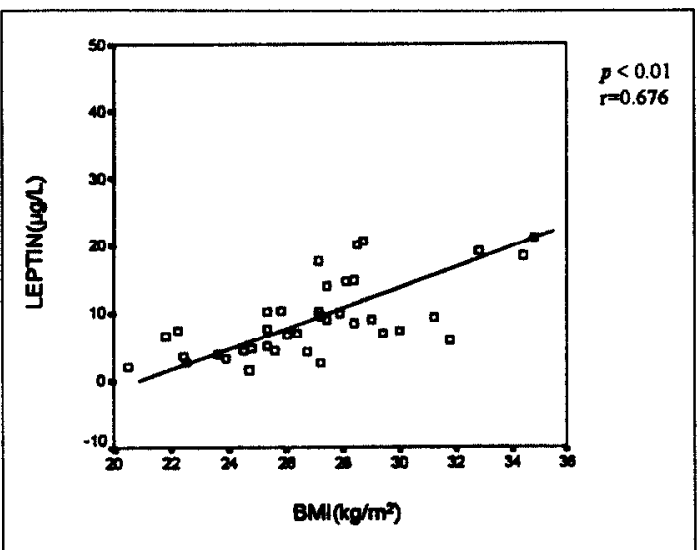

Fig. 4. Correlation between serum leptin concentration and body mass index(BMI) in patients with obstructive sleep apnea.

과도 상관관계가 없었다.

수면무호흡중의 혈중 leptin 농도와 인체계측인자 및 수면다원검사상 소견과의 선형 상관관계를 비교한 결과 수면무호합중군에서의 혈중 leptin 농도와 인체 계측인자로 체중 $(\mathrm{r}=0.484, \mathrm{p}<0.01)$, 신체질량지수 $(\mathrm{r}=0.369, \mathrm{p}<0.01)$ 와는 유의한 선형 상관관계가 있 었다(Fig. 4). 수면무호훕중에서 leptin 농도와 수면

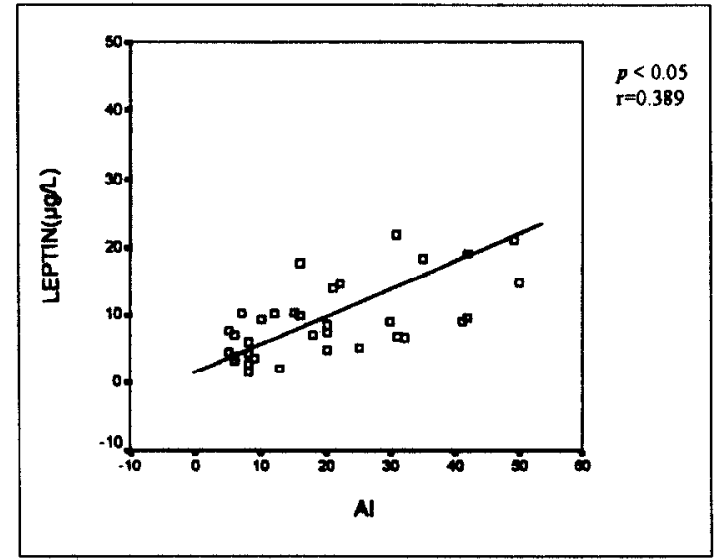

Fig. 5. Correlation between serum leptin concentration and apnea index $(\mathrm{AI})$ in patients with obstructive sleep apnea.

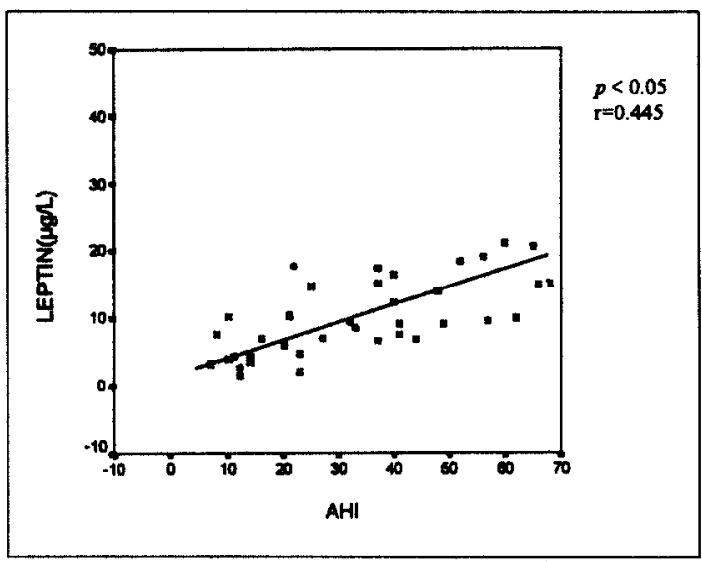

Fig. 6. Correlation between serum leptin concentration and apnea-hypopnea index(AHI) in patients with obstructive sleep apnea.

다원검사상의 REM 수면과는 상관관계가 없었으나, 무호흡의 중중도와 관계 있는 무호흡지수 $(r=0.389$, $p<0.05)$ (Fig. 5), 무호흡 - 저호협지수 $(r=0.445, p$ $<0.05)$ (Fig. 6), 동맥혈 최저산소포화도 $(r=-0$. $608, \mathrm{p}<0.01$ )(Fig. 7) 및 동맥혈 평균산소포화도(r $=-0.663, p<0.01)$ 와는 유의한 선형 상관관계가 있 었다.

수면무호합중에서 안정시 에너지소모량의 백분울과 


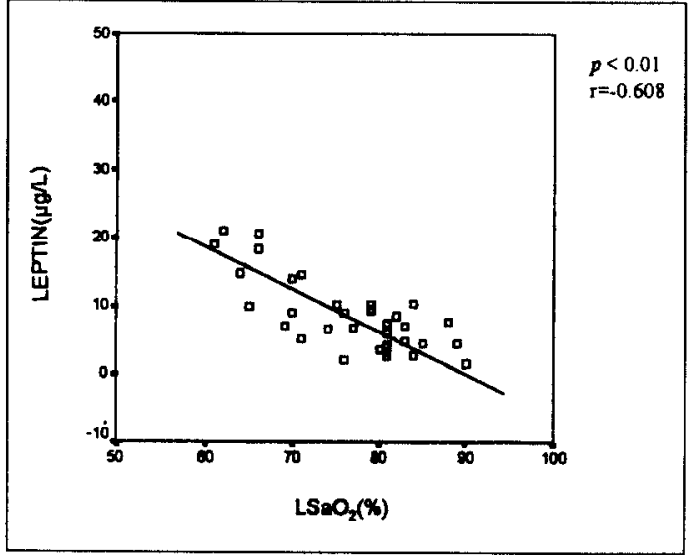

Fig. 7. Correlation between serum leptin concentration and lowest arterial oxygen saturation $\left(\mathrm{LSaO}_{2}\right)$ in patients with obstructive sleep apnea.

혈중 leptin 농도의 선형 상관관계를 비교한 졀과 기 대한 바와는 달리 이들 사이에 상관관계는 없었다 (Fig. 8).

\section{고 찰}

Browman 둥 ${ }^{5)}$ 은 수면무호흡중 환자의 체중변화와 무호흡 중상의 변화를 관찰한 결과 체중조절로 수면 중 발생하는 무호홉 발생빈도가 감소하고, 동맥혈 산 소포화도와 심부정맥이 호전됨을 관찰하였고, $\mathrm{Har}$ $\operatorname{man}$ 둥 ${ }^{4}$ 도 비숫한 결과를 보고함으로써 비만이 수면 무호합중의 충요한 원인으로 생각하게 되었다. 이와 같은 사실은 수면무호흡중 치료에 체중조절이 중요하 다는 것을 의미하지만 현재까지 비만조절을 위하여 시 도되고 있는 식이요법, 행동치료 및 심리치료 둥이 부 분적으로는 성공을 거두었으나 장기적인 성공에는 한 계를 보여 치료결과는 만족스럽지 못하다 ${ }^{1,6)}$.

체중은 에너지 섭취와 소비에 의하여 결정되고, 일 일 총 에너지소모량(total energy expenditure)은 안정시 에너지소모량(resting energy expenditure), 식사로 인한 열생성(dietary thermogenesis), 운동 에 의한 열생성(thermic effect of exercise) 그리고

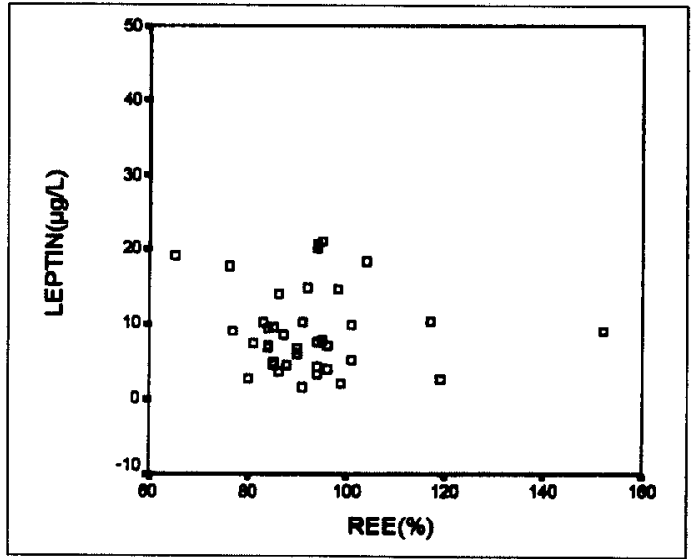

Fig. 8. Correlation between serum leptin concentration and resting energy expenditure (REE) in patients with obstructive sleep apnea.

온도, 스트레스 둥 외부환경 변화에 적웅하기 위하여 생성되는 열(facultative thermogenesis)로 구성된 다. 이 중 약 $70 \%$ 정도가 안정시 소모되는 에너지량 에 의하여 결정되며, 하루 생활 중 에너지 대사율은 잠들 때 감소하기 시작하여 이른 아침에 가장 낮은 일 일 변화 주기성을 보이며, 정상적인 환경의 수면상태 는 각성시 보다 약 $10 \%$ 정도 에너지 소비가 줄어든 다 ${ }^{7.8)}$.

저자들은 비만한 폐쇄형 수면 무호합중 환자는 주간 의 과다한 즐음과 무호흡에 의하여 생기는 저산소혈중 으로 정상적으로 생활할 때보다 안정시 에너지소모량 이 감소하고 대사량의 감소는 체중을 더욱 중가시켜, 수면 무호합중을 더욱 악화시킬 것으로 가정하였다. 그러나 조사 결과 폐쇄형 수면 무호흡중 환자의 안정 시 에너지소모량은 비숫한 비만도를 보이지만 무호흡 이 없는 대조군에 비하여 차이가 없었으며 환자의 나 이. 키, 체중, 목둘레, 신체질량지수 둥 일반적인 신체 계측지수와 무호흡의 중증도와 관계있는 무호흡지수, 무호흡 - 저호흡지수 및 최저 산소포화도와도 유의한 상관관계가 없었다. 이러한 결과는 연구의도와 차이가 있으며, 폐쇄형 수면 무호홉증 환자의 비만이 난순히 안정시 에너지소모량의 감소에 의한 것이 아니라 다른 
- The relationship of the severity of sleep apnea syndrome to the resting -

기전이 채중을 유지하는데 중요한 역할을 하고 있음은 의미하는 것이다.

Ravussin 등 ${ }^{11}$ 과 Bonnet 둥 ${ }^{(2)}$ 은 수면 중 에너지 소모량 연구에서 수면 중 각성과 각성에 따른 산소 섭 취량 및 이산화탄소 생성량의 중가가 에너지소비룰 중 가시키고, Fletcher 등-13)은 수면 증 반복되는 무호흡 은 교감신경을 활성화시켜 상기도 폐쇄에 대한 호홉노 력의 증가로 에너지소모가 늘어난다고 주장하였으며, Stenlöf 등 ${ }^{16)}$ 은 폐쇄성 수면 무호흡중에서 수면 중 중가된 에너지소모량은 비강을 퉁한 지속적 기도양압 (nasal positive airway pressure)을 적용한 결과 에 너지 소모가 감소됨을 보고하였다. 이러한 사실들은 수면 중 발생하는 반복적 각성과 호흡노력 중가에 따 른 에너지 대사 중가가 비만을 일으키는 요인과 균형 을 이루지 못 할 정도로 작다는 것을 의미하고, 이것 은 저자들의 연구 결과와 비숫한 것이라 할 수 있겠 다. 비만이 무절제한 음식섭퀴나 에너지소모량 감소에 의한 것보다는 체은이나 삼투압 유지와 같이 새로이 설정된 상숭된 기준(elevated set-point)에 의하여 유지된다는 Keesy 등(5)의 설명과, Corbett 둥 ${ }^{(6)}$ 은 동룰실험에서 비만한 쥐의 단위체중 당 에너지소모는 정상 체중의 쥐와 동일하나 음식궁급을 줄이면 안정시 에너지소모량은 체중을 계속 유지시킬 정도로 감소하 여 원래의 체중을 유지한다는 사실을 밝혔다. 즉 지속 적으로 고열량 식이를 공급하면 처음의 체중을 유지하 기 위하여 에너지소모량이 중가하지만, 계속 고열량 식이률 공급하면 이러한 반웅은 소실되고, 시상하부의 체중조절기준이 새로 설정되어 새로 설정된 체중에 도 달하게 된다는 것이다. 그리고 금식과 같은 식이 환경 의 변화가 있어도 새로 설정된 체중을 유지하기 위하 여 안정시 에너지 소모량이 감소하여 체중을 유지하게 된다. 이러한 것을 식이성 비만(diet induced obesity)이라 한다 ${ }^{17}$. 폐쇄형 수면 무호흡중의 에너지 대사 이상에도 블구하고 지속적으로 체중이 중가하는 것온 이러한 식이성 비만이 주요한 기전으로 작용하리라 생 각한다.

또한 비만한 사랍은 혐중 leptin 농도가 중가되어
있으며 leptin은 167 개의 아미노산으로 구성되고 ob 유전자에 의하여 백색지방세포(whitie adipose tissue)에서 생성되는 $16 \mathrm{KDa}$ 의 단백질이다. leptin은 시상하부에 작용하여 음식섭취를 줄이고 에너지소모 를 중가시켜 체중을 줄이는 작용을 한다 ${ }^{18-20)}$. 비만한 사랍의 약 $5 \%$ 정도만 체지방에 비하여 leptin 농도 가 감소해 있을 뿐 대부분 비만한 사랍은 혈 중 leptin 농도가 높다 ${ }^{21-231}$. 그러나 leptin 농도가 중가 해 있음에도 불구하고 비만한 것은 leptin 작용기전에 대한 저항성을 원인으로 Caro 둥ㅎㅇ은 제시하고 있다.

저자들의 연구에서 헐중 leptin 농도는 수면 무호합 증 환자 및 대조군 사이에 유의한 차이는 없었으나, 수면 무호홥중의 중중도과 관계 있는 무호협지수, 무 호흡 저호흡지수 및 동맥혈 최저 산소포화도와 상관 관계가 있었다. 이러한 사실이 수면무호합중에서만 나 타나는 특이한 현상인지는 분명하지 않지만, 수면 무 호흡중의 중중도의 요인으로 작용할 수 있는 비만과 관계가 있을 것으로 생각한다. 또한 수면 무호흡중에 서 안정시 에너지소모량의 백분을과 혈중 leptin 농도 와 상관 관계가 없었던 결과로 보아 수면무호합중에서 leptin은 안정시 에너지소모를 중가시켜 체내 지방을 조절하기보다는 식이를 조절함으로쎄 체지방을 조절 할 것으로 생각된다. Saarelainen 둥ㄴ)은 폐쇄성 수 면 무호흡중에서 약 3 개월 동안 비강을 통한 지속적 양압 치료 후 혈중 leptin 농도가 치료 전보다 감소하 였다고 보고하고, 지속적 양압 치료 후 hypothalamic negative feedback 기전의 활성화로 설명하였 다. 이와 갆은 결과는 폐쇄성 수면 무호함중에서 혈 중 leptin 농도가 상숭된 것은 단순히 비만에 의한 것 이라기보다 수면 무호흡중의 중증도와 관계가 있을 것 으로 추측할 수 있다.

이상의 결과로 폐쇄형 수면 무호흡중에서 안정시 에 너지소모량의 감소는 없으며, 무호흡의 정도가 심할수 록 혈중 leptin 농도가 높았다. 이것은 수면무호합중 에 동반되는 비만은 단순히 안정시 에너지대사 감소에 의한 것보다는 시상하부의 체중조절중추에서 체중조 절 기준이 높게 설정되어 있었기 때문으로 생각한다. 
수면무호홉중에서 leptin은 안정시 에너지소모에 관여 하여 지방을 조절하기보다는 식이를 조절함으로써 체 지방을 조절할 것으로 생각하고, 혈중 leptin 농도는 수면 무호흡중에 동반된 비만과 관계가 있을 것으로 생각하지만, 비만 이외 무호흡의 중증도와 관계 있는 다른 원인과의 관계에 대해서는 더 연구가 이루어져야 할 것으로 생각한다.

\section{요 약}

연구배경 :

수면 무호홉증 환자는 대부분 비만이 동반되고 비만은 수면 무호흡중 발병의 중요한 원인으로 알려져 있다. 또한 체중을 줄임으로써 무호흡 횟수 및 심부정맥의 감소와 동맥혈 산소포화가 향상된다는 사실이 알려지 면서 체중조절을 중요한 치료방법으로 생각하게 되었 다. 그러나 지금까지 비만에 대한 다양한 치료방법이 시도되었으나 결과는 만족스럽지 못하다. 저자들은 체 내에너지 대사의 대부분을 차지하는 안정시 에너지대 사의 변화를 관찰하고 수면다원검사에서 측정한 수면 무호흡중의 중중도와 안정시 에너지소모량과의 상관 관게를 규명하여 무호훕의 중중도가 안정시 에니지대 사에 미치는 영향을 알아보았다. 또한 수면 무호흡중 에서 혈중 leptin 농도를 측정하여 수면 무호홉의 중 증도와 leptin과의 상관관계를 알아보기 위하여 이 연 구를 수행하였다.

방 법:

수면 중 무호홉 증상을 주소로 내원하여 수면무호흡중 으로 진단 받은 환자 중 신체질량지수가 $25 \mathrm{~kg} / \mathrm{m}^{2}$ 이 상인 39 례와 비숫한 비만도를 보이며 수면무호흡이 없었던 45 례를 대상으로 수면다원검사를 실시하고 안 정시 에너지소모량은 ventilated hood system을 이 용하여 indirect calorimetry로 측정하였다. 수면무 호합중과 대조군에서 혈중 leptin 농도는 human leptin kit를 사용하여 축정하였다.

겼 과:

수면무호흡증은 대조군보다 안정시 에너지소모량의
예측치와 측정치가 유의하게 높았으나, 안정시 에너지 소모량 백분율은 차이가 없었다. 안정시 에너지소모량 은 수면무호흡중의 중중도와 관계 있는 무호합지수, 무호흡 - 저호흡지수 및 최저 동맥혈 산소포화도 등과 도 상관관계는 없었다. 수면무호흡중에서 혈중 leptin 농도는 무호흡지수, 무호흡 - 저호흡지수 및 최저 동 맥혈 산소포화도와 상관관계가 있었으나, 안정시 에너 지소모량과 상관관계는 없었다.

\section{결 론:}

이상의 결과로 수면무호흡증에서 안정시 에너지대사 가 감소되어 있지 않았으며 수면무호흡중에서 leptin 은 안정시 에너지소모에 관여하여 지방을 조절하기보 다는 식이를 조절함으로써 체지방을 조절할 것으로 생 각한다. 수면무호흡중에서 무호흡의 정도가 심할수록 혈중 leptin 농도가 높았으며 이는 수면무호흡중에 동 반된 비만과 관계가 있을 것으로 생각하며, 수면무호 흡중에서 leptin 농도와 무호홉의 중중도와의 관계에 대해서는 더 많은 연구가 펄요할 것으로 생각한다.

\section{참 고 문 헌}

1. Guilleminault C, Eldridge FL, Tilkian A, Simmons FB, Dement $\mathrm{W}$ : Sleep apnea syndrome due to upper airway obstruction. Arch Intern Med 137 : 296, 1977

2. Marcus CL, Koerner CB, Pyzic PL, Loughlin GM : Determinants of growth faihure in children with the obstructive sleep apnea syndrome. Am Rev Respi Dis 147 : A761, 1993

3. Guilleminault C, Tilkian A, Dement W: The sleep apnea syndromes. Am Rev Med 27 : 465, 1976

4. Harman EM, Wynne JW, Block AJ : The effect of weight loss on sleep disordered breathing and oxygen desaturation in morbidly obese men Chest $82: 291,1982$

5. Browman CP, Sampson MG, Yoller SF : Obstructive sleep apnea and body weight. Chest $85: 435$, 
- The relationship of the severity of sleep apnea syndrome to the resting -

1984

6. Fisher JP, de la Pena A, Mayfield D, Frickinger $\mathrm{R}$ : Starvation and behaviour modification as a treatment in obese patients with sleep apnea : A follow up. Sleep Res $7: 222,1978$

7. Horton ES : An overview of the assessment and regulation of energy balance in humans. Am J Clin Nutr 38 : 972, 1983

8. Goldberg GR, Prentice AM, Davies HL, Murgatroyd PR : Overnight and basal metabolic rates in men and women. Eur J Clin Nutr 42 : 137,1988

9. Caro JF, Sinha MK, Kolaczynski LW, Zhang PL, Considine RV : Leptin: The tale of an obesity gene. Diabetes $45: 1455,1996$

10. Campfield LA, smith FJ, Burn P: The ob protein (leptin) pathway a link between adipose tissue mass and central nervous networks. Horm Metab res $28: 619,1996$

11. Ravussin E, Rising $R$ : Daily energy expenditure in humans : measurements in a respiratory chamber and by double labeled water. In Energy metabolism : tissue determinants and cellular corollaries, Kennedy JM and Tucker HN : New York: Raven, 1992.

12. Bonnet MH, Berry RB, Arandl DL : Metabolism during normal, fragmented and recovery sleep. $\mathrm{J}$ Appl Physiol $71: 1112,1991$

13. Fletcher EC, Miller J, Schaaf JW, Fletcher JG : Urinary catecholamines before and after tracheostomy in patients with obstructive sleep apnea and hypertension. Sleep $10: 35,1987$

14. Stenlöf K, Grunstein R, Hedner J, Sjöström L : Energy expenditure in obstructive sleep apnea : Effects of treatment with continuous pasitive airway pressure. Am J Physiol 271 (Endocrinol Metab 34) : E1036, 1996
15. Keesey RE: Physiological regulation of body weight and the issue of obesity. Med Clin North Am $73: 15,1989$

16. Corbett SW, Stern JS, Keesey RE : Energy expenditure in rats with diet induced obesity. Am J Clin Nutr $44: 173,1986$

17. Bray GA : Effect of caloric restriction on energy expenditure in obese patients. Lancet $2: 397$, 1969

18. Auwerx J, Staels B : Leptin. Lancet $351: 737$, 1998

19. Zhang Y, Proenca R, Maffei M, Barone M, Leopold L, Friedman JM : Positional cloning of the mouse obese gene and its human homologue. $\mathrm{Na}$ ture $372: 425,1994$

20. Pellymounter MA, Cullen MJ, Baker MB, et al : Effect of the obese gene product on body weight regulation in ob/ob mice. science $269: 540,1995$

21. Considine RV, Considine EL, Williams CJ, et al : Evidence against either premature stop codon or the absence of obese gene mRNA in human obesity. J Clin Invest $95: 2986,1995$

22. Considine RV, Sinha MK, Heiman ML, Kriauciunas A, Stephens TW, Nyce MR, Ohannesian JP, Marco CC, McKee LJ, Bauer TL, Caro JF : Serum immunoreactive-leptin concentrations in normal-weight and obese humans. $\mathrm{N}$ Engl J Med 334 : 292, 1995

23. Maffei M, Halaas J, Ravussin E, Pratley RE, Lee $\mathrm{GH}$, Zhang $\mathrm{Y}$, Fei $\mathrm{H}$, Kim S, Lallone $\mathrm{R}$, Ranganathan S, Kern PA, Friedman JM : Leptin levels in human and rodent: Measurement of plasma leptin and Ob RNA in obese and weightreduced Subjects. Nature Med $1: 1155,1995$

24. Saarelainen S, Lahtela J, Kallonen E : Effect of nasal CPAP treatment on insulin sensitivity and plasma leptin. J Sleep Res 6 : 146, 1997 